\title{
a-ジケトンを含むポリアミドおよびその キノキサリン誘導体の合成
}

(1976 年 11 月 11 日受理)

長久保国治・阿久津文彦・河 村 信 夫夫三浦正敏*

主鎖に $\alpha$-ジケトン結合を含をジカルボン酸クロリド $\left(4,4^{\prime}\right.$ ービス(クロロホルミル)ベンジル)を合成 し，種々の劳香族ジアミンとの反応によってポリアミ゙゙を合成した。重合は $5 \mathrm{wt} \% \mathrm{LiCl}$ を含む $N-$ メ

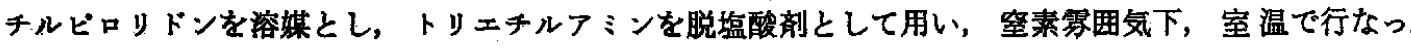
た。つぎK, 得られたポリアミドKoーフェニレンジアミンを反応させ，キノキサリン懪を導入したボ：

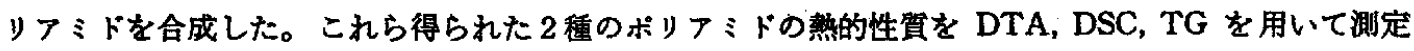

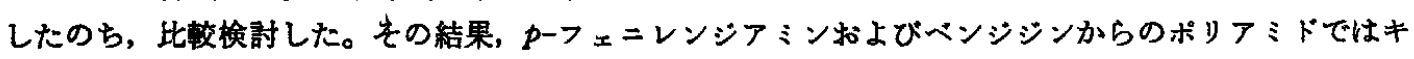
ノキサリン導入の影響は見られなかったが， $m$ ーフェニレンジアミンおよびジフミノジフェニルエーテ ルからのポリアミドでは, 耐熱性がいちじるしく向上することが認められた。

\section{1 楮 春}

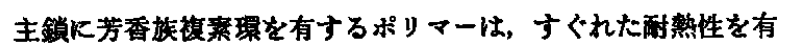
することが知られており，耐熱性高分子として今日まで数多く 合成されている。その中の一つであるボリキノキサリンは Stille $5^{(1)}$ (a), Hergenrother $5^{(1) 8)}$, Wrasidlo $5^{(0)}$ (10), Hagnauer $5^{(1)}$,

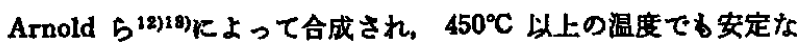
耐熱性のすぐれたボリマーとして報告されている。それらはいず れる主鎖にキノキサリン環を有するるのであるが，㑡鎖にるつる のはいまだ報告されていない。すぐれた熱性を示すこのキノキ

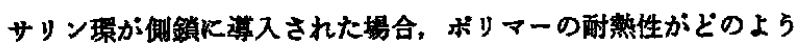
に影簤を受けるか恃興味あるところである。

本研究ではつぎに示すよらに，主鎖に $\alpha$-ジケトン結合を含を ボリアミド[1]を合成し，このポリフミド[1]K高分子反応に よって湖鎖にキノキサリン環を学入したポリフミド〔2〕を合成 した。これら得られた 2 種のポリアミドの性筫，とくに熱的性質 を比較検討した結果，若千の知見が得られたのでここに報告す

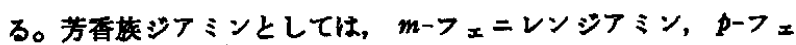
ニレンジフミン, 4, $4^{\prime}$-ジアミノジフェニルェーテル, ベンジジン を用いた。

* 千菜大学工学暗合成化学料, 280 千葉市弥生町

1) J.K.Stille, J. R. Williamson, J. Polym. Sci., B-2, 209 (1964).

2) J. K. Stille, J.R. Williamson, ibid., A-2, 3867(1964).

3) J.K. Stille, J.R. Williamson, F.E. Arnold, ibid., A-3, 1013(1965).

4) P.M. Hergenrother, ibid., A-1, 6, 3170(1968).

5) P.M. Hergenrother, D.E.Kiyohara, Macromolecules, 3. 387(1970).

6) W. Wrasidlo, J.M. Augl, J. Polym. Sci., A-1, 7, 3393 (1969).

7) W. Wrasidio, J. M. Augl, ibid., B-8, 69(1970).

8) W. Wrasidlo, J. M. Augl, Macromolecules, 3, 544 (1970).

$$
\underset{O=}{\longrightarrow}
$$

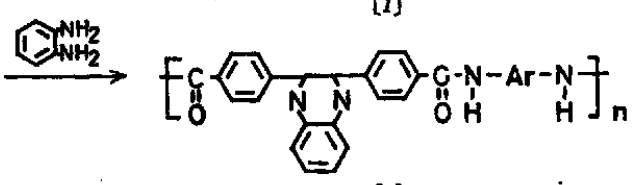

[2]

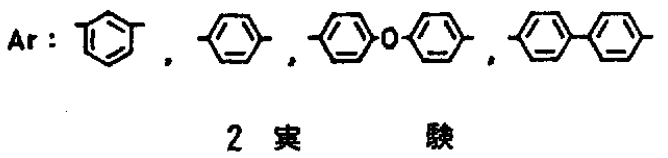

IR スペトクルの測定には日立製作所 EPI-G 2 形回折格子赤外

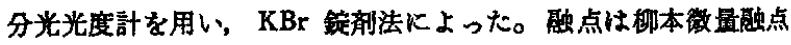
测定装居 MP-S 2 型を用いた。可視吸收スベトクルの测定には日 立製作所 EPS-3 T 形自記分光光度計を, NMR は日立製作所 R24 核磁気共鳴装置を使用した。DTA，DSC，TG は理学奄機(株) TG-DTA 高温形 (Cat. No.8076 D 1), TG-DSC 標準形 (Cat. No. 8085 D 1), DSC 高温形 (Cat. No. 8056) を用い, 窒素気流 中 $(50 \mathrm{ml} / \mathrm{min})$ で測定した。

\section{1 鼓 薬}

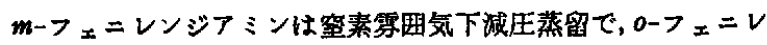
ンジフミンおよび pーフェニレンジアミンは昇華法により精製し

9) W. Wrasidlo, J. Polym. Sci., A-1, 8, 1107(1970).

10) W. Wrasidlo, ibid., A-2, 9, 1603(1971).

11) G. L. Hagnauer, G. D. Mulligan, Macromolecules, 6, 544(1973).

12) F.E. Arnold, J. Polym. Sci., A-1, 8, 2079(1970).

13) F. L. Hedberg, F. E. Arnold, ibid., A-1, 12, 1925(1974). 
た。 $N$-メチルピロリドン（以下 NMP と略記する）は市肘品をへ ンゼンで共沸脱水後, 空素等围気下で減庄蒸留し，モレキュラー シーブ 4 A上で貯蔵した。その他, 本研究に用いた試薬, 溶媒は 南肘品をそのままか、かるいは常法にしたがい精製したるのを用 いた。

$2.24,4$ 4'ビス(クロロホルミル)ベンジルの合成 つぎの経路で合成した。

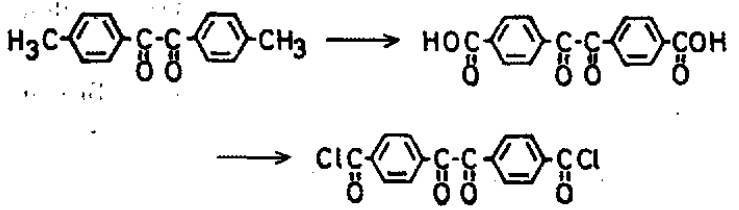

Braun'4) の方法にしたがって合成した 4,4'-ジメチルベンジル $23.8 \mathrm{~g}(0.1 \mathrm{~mol})$ を酢酸 $300 \mathrm{ml}$, 無水䤏酸 $100 \mathrm{ml}$, 篧硫酸 $2 \mathrm{ml}$ の溶泎に加光，かきまぜながら $60^{\circ} \mathrm{C}$ で酸化クロム(V) $42 \mathrm{~g}$ を

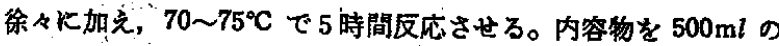
蒸留水中に注き，得られた沈殷物を水で上く洗浄する。炭酸ナト リウム水溶液でナトリゥム塩として溶解させ，文䋘物を汇過し たのち，塩酸酸性にしてジカルポン酸を得る。粗取量 $25.6 \mathrm{~g}$ (86 \%)。このジカルボン酸には副生成物としてモノカルポン酸（4カルボキシー4'メキルベンジル）および $\alpha$ がジトン結合が切断 されたテレフタル酸が含まれており、これらは再結晶により十分 除去されないため，そのまま酸クロリドに尊いて精製した。

4, 4'-ジカルボキシベンジル $51.8 \mathrm{~g}(0.17 \mathrm{~mol})$ をトルムン 550 $\mathrm{ml}$, 塩化チオニル $203 \mathrm{ml}, \mathrm{DMF}$ 数滴の中で 10 時間還流させた のち，常正で過剩の塩化チオニルを除去し，目的物を得る。ベン ゼンで再結晶をくり返す。黄色針状結晶。収量 $42.7 \mathrm{~g}(75 \%), \mathrm{mp}$ $190 \sim 191^{\circ} \mathrm{C}_{\circ}$

分析倠 $\mathrm{Cl} \mathrm{21.72 \%}$

$\mathrm{C}_{18} \mathrm{H}_{8} \mathrm{O}_{4} \mathrm{Cl}_{2}$ としての羽其値 $\mathrm{Cl} 21.16 \%$

\section{3 モデル化合物の合成}

2.3.1 4,4'-ピス(フェニカルパモ1ル)ベンジル[3]の合成： 4, 4'ビス(クロロホルミル)ベンジル $2.146 \mathrm{~g}(0.004 \mathrm{~mol})$ と大過 剩のアニシン $51 \mathrm{ml}$ とを室温で 3 時間かきまぜる。度終了後， 多量の希塩酸（瀑塩酸 $50 \mathrm{ml}$, 蒸留水 $800 \mathrm{ml}$ ) に内容物を注ざ, 生じた沈股物をニトロベンゼンで再結晶する。淡黄白色板状結 晶。取量 $1.78 \mathrm{~g}(99 \%)$, mp $296^{\circ} \mathrm{C}$ 。

分析值 C $75.27 \%, \mathrm{H} 4.34 \%, \mathrm{~N} 6.15 \%$

$\mathrm{C}_{28} \mathrm{H}_{20} \mathrm{O}_{4} \mathrm{~N}_{2}$ としての

訫算値 C 74.99\%，H 4.50\%，N 6.25\%

NMR(DMSO- $d_{3}$, TMS-絜準) (ppm) : 10.4(s) N-H, 8.25 7. $0(\mathrm{~m}) \mathrm{Ar}-\mathrm{H}$

2.3.2 2,3-ピス[4-(フェニルカルハモモイ フェニル]キノキ サリン[4]の合成 : 4,4'ビス(フェニルカルバモイル)ヘンジル $1.794 \mathrm{~g}(0.004 \mathrm{~mol})$ JMP $15 \mathrm{ml}$ に溶がし，公温でがきぜ ながら, NMP $5 \mathrm{mlk0ーフェニレンジフミン} 0.433 \mathrm{~g}(0.004 \mathrm{~mol})$ を溶かした溶液を滴下する。70C で 2 時間かきまぜたのち，溶 液を $400 \mathrm{ml}$ の蒸留水に注ぎ沈殿物を得る。のージクロロペンゼン で再結晶する。白色針状結晶。取量 $2 \mathrm{~g}(96 \%), \mathrm{mp} 260^{\circ} \mathrm{C}$ 。 分析値 C $78.48 \% ，$ H $4.38 \%$ ，N $10.50 \%$

14) W.Braun, D.R.P., 913,891(1954).
$\mathrm{C}_{34} \mathrm{H}_{24} \mathrm{O}_{2} \mathrm{~N}_{4}$ としての

計算值 C $78.44 \%$ ，H 4.65\%，N $10.76 \%$

NMR (DMSO- $d_{6}$, TMS-標帮) (ppm) : 10.2(s) N-H, 8.35 6. 85(m) Ar-H

\section{4 ホリアミドの合成}

一例をつぎに示す。4,4'ービス（クロロホルミル)ベンジル 3.3517 $\mathrm{g}(0.01 \mathrm{~mol})$ に塩化りチウムを含む NMP(NMP $40 \mathrm{ml}, \mathrm{LiCl} 1 \mathrm{~g}$ ) $35 \mathrm{ml}$ Kベンジジン $1.8473 \mathrm{~g}(0.01 \mathrm{~mol})$ を溶かした海液を窒素 票囲気下，室温でかきまぜながら滴下する。滴下漏斗を牫りの NMP (含 LiCl) $5 \mathrm{ml}$ で洗い，最後にトリェキルフミン $3 \mathrm{ml}$ を 加える。ただちに塩酸㙁が析出する。室温で 7 時間かきまぜたの ち，反応生成物をメタノール水溶液 $(380 \mathrm{ml}+380 \mathrm{ml})$ K注ぎ， 沈股物を得る。メタノールと蒸留水でよく洗浄後、娍王乾燥与 る。取量 $4.742 \mathrm{~g}(104 \%), \eta_{\mathrm{inh}} 0.35\left(0.5 \mathrm{~g} / 100 \mathrm{ml}\right.$ conc. $\mathrm{H}_{2} \mathrm{SO}_{4}$, $30^{\circ} \mathrm{C}$ )。

\section{5 高分于反必}

一例をつぎに示す。 4,4'-ピス（クロロホミル)ペンジルと m$フ_{x}=$ レンジフミンからのポリフミト $1.8518 \mathrm{~g}$ (くり返し単位モ ル数 $0.005 \mathrm{~mol}$ )を $0.25 \mathrm{~g}$ の塩化りキウムを含む NMP $25 \mathrm{ml}$

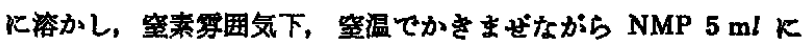
のーブニレンジフミン $0.5467 \mathrm{~g}(0.005 \mathrm{~mol})$ を溶かした溶液を滴 下する。 $70^{\circ} \mathrm{C}$ で 2 時間反纯させたのち，反応液を $500 \mathrm{ml}$ のメ タノール中に注き沈股物を得る。蒸留水てよく洗浄後、減圧乾嬠 する。収量 $1.19 \mathrm{~g}(54 \%), \eta_{\mathrm{inh}} 0.26\left(0.5 \mathrm{~g} / 100 \mathrm{ml}\right.$ conc. $\mathrm{H}_{2} \mathrm{SO}_{4}$, $\left.30^{\circ} \mathrm{C}\right)$ 。

\section{3 結果と考察}

\section{1 モデル化合物の合成}

重粳合にさき立ち，ポリフミドとの比教のためにモデル化合物 の合成を行なった。

4,4'-ビス(フェニルカルバモイル)ベンジル[3]は, 4, 4'-ビス （クロロホルミル)ベンジルを大過剩のアニリンと室温で反応させ， 99\% の高收率で得た。元素分析 (実験の項参照)，IR, NMR K より橉造を確認した。IR では, $3320 \mathrm{~cm}^{-1} に \nu_{\mathrm{N}-\mathrm{H}}, 1650 \mathrm{~cm}^{-1}$

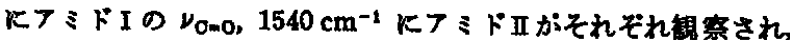

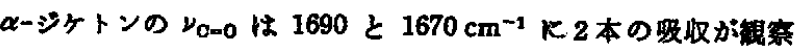
された。また，硫酸溶媒中可視吸取スペトクルの吸取はなかっ た。

つぎに〔3]を等モルののーフニンンジフミンと反応させ，2，

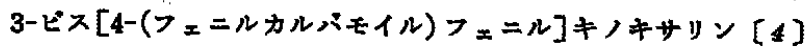
を合成した。反応は NMP 中 $70^{\circ} \mathrm{C} て ゙ 2$ 時間行ない，収量よく得 られた。〔4]の確認は元䓶分析 (実倹の項参照)，NMR, IR, 可 視吸収スペトクルで行なった。IRでは、 $\nu_{N-H}$ は $3325 \mathrm{~cm}^{-1}, 7$ ミドIの $\nu_{0-0}$ は $1660 \mathrm{~cm}^{-1}$ へと、それぞれ中中高波数にシフ トしている。〔3]に見られた $\alpha$ ージケトンの 2 本の曼取は完全に 消失し，かわりに 0-覧換ベンゼンの $1060 \mathrm{~cm}^{-1}$ の服收が現われ た。〔4〕は有機溶媒に溶かすと中や黄色く着色する程度であるが， 渚硫酸に溶かすと赤く発色する。この現象は[3]には見られな かったものである。キノキサリンに硫酸塩が存在する15)ことから. この発色は塩形成に上るるのと思われる。硫誜中における反结前 後の可視吸取スペトクルの变化を図 1 に示す。[\&]には $431 \mathrm{~nm}$

15) "The Merk Index", 8 th Ed., p.908(1968). 
《N-C-

[3]

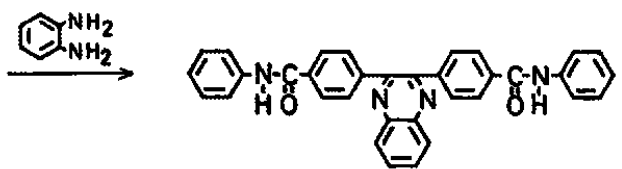

[4]

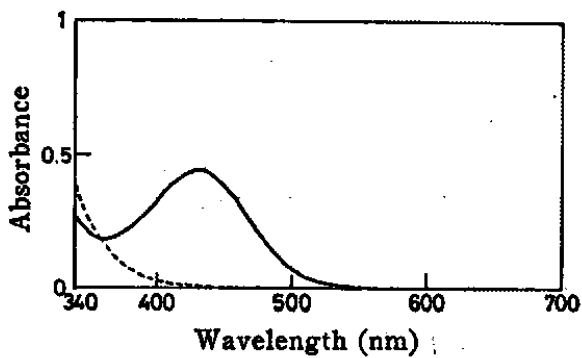

Fig. 1 Visible spectra of model compounds in conc. $\mathrm{H}_{2} \mathrm{SO}_{4}$

$---:[3] 2.68 \times 10^{-6} \mathrm{~mol} / \mathrm{l}$

- : [4]. $2.54 \times 10^{-5} \mathrm{~mol} / l, \lambda_{\max }=431 \mathrm{~nm}(\varepsilon=17200)$

に吸収極大が現われている。

\section{2 ボリアミドの合成}

4,4'ーピス(クロロホルミル)ベンジルは有譏溶媒に対する溶解 性がいちじるしく低く，NMP などの極性溶媒にも溶けにくい。 しかし，ジフミン溶液には上く溶けることを見いだしたので，重 樎合は，固体のジルボン酸クロリドに, NMP (含 $\mathrm{LiCl}$ ) K溶 かしたジフミン溶液を滴下する万法で行なった。林トン結合 を含むこのタイプのポリアミドを[1]とする。ジフンとして

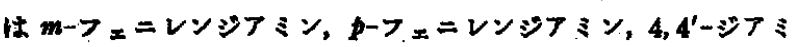
フジフェニルエーテル, ベンジジンを用いた。重縮合結果を表 1 飞示す。

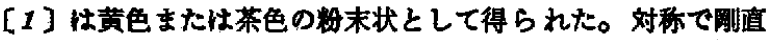
な $p$ ーフェレンジフミンおよびベンジジンかのボリフミドは 茶色で, 非対称の $m$-フェニレンジフミン, 屈曲性のある 4, $4^{\prime}$ ジフミノジフェルエーテルからのボリアミドは黄色である。 〔1]の構造はモデル化合物〔3]とのIR の比較により確認し
Table 1 Results of polycondensation

\begin{tabular}{|c|c|c|c|c|c|}
\hline $\mathrm{Ar}$ & $\begin{array}{l}\text { Reaction } \\
\text { time(hr) }\end{array}$ & $\begin{array}{l}\text { Yield } \\
(\%)\end{array}$ & $\begin{array}{l}\eta_{\left(n h^{a)}\right.} \\
(d l / g)\end{array}$ & $\begin{array}{l}\eta_{\left.\ln h^{a}\right)} \\
(\mathrm{d} l / g)\end{array}$ & Color \\
\hline & 17.5 & 94 & 0.26 & $0.31^{b)}$ & Yellow \\
\hline & 12 & 106 & 0.33 & $\left.0.57^{b}\right)$ & Brown: \\
\hline & 27 & 82 & 0.37 & $0.52^{b)}$ & Yellow \\
\hline & 7 & 104 & 0.35 & $-^{c)}$ & Brown \\
\hline
\end{tabular}

a) $0.5 \mathrm{~g} / 100 \mathrm{ml}$ conc. $\mathrm{H}_{2} \mathrm{SO}_{\text {, at }} 30^{\circ} \mathrm{C}$.

b) After treating at $150^{\circ} \mathrm{C}$ in vacuum for $2.5 \mathrm{hr}$.

c) Partially soluble after treating at $250 \sim 300^{\circ} \mathrm{C}$ in vacuum for $2.5 \mathrm{hr}$.

た。 $\eta_{\operatorname{lnh}}$ 仕湌硫酸中 0.26〜0.37であった。これらのポリアミド を固相状態で真空下加熱処理すると， $\eta_{\text {Inh }}$ がそれぞれかなり高 くなった。熱処理前後の IR がまったく変わっていないことから， 重縮合以外のポリマーの構造に変化をすたらす反応が起こってい るとは考えにくい，したがって，䀓処理により低分子のるのが脱 離して重合が進み，分子量が増大したといえる。ベンジジンから のポリフミドは他の場合と異なり，より高温で行なったところ， 溶媒に可溶な部分と不溶な部分とが生じた。不溶部は三次元化し たるのと思われる。

\section{3 高分子反応}

[1]にくり返し単位に対して等モルの 0 ーフェニレンジフミン を反㤁させることにより，キノキサリンを含むボりフミド〔2〕 を得た。結果を表 2 に示す。

反応温度 $70^{\circ} \mathrm{C}$, 咥素雾囲気下，塩化りチウムを含む NMP 中 で 2〜4 時間反応を行なった。ベンジジからのポリアミ゙ド除 き，反応は均一系で行なわれた。生成物の構造はモデル化合物と のIRおよび可視吸収スヘトクルの比較により確認しだ。IRでは $\nu_{\mathrm{C}=0}$ の $1670 \sim 1680 \mathrm{~cm}^{-1}$ が $1660 \mathrm{~cm}^{-1}$ へとやや低波数へシフ トし， $1060 \mathrm{~cm}^{-1}$ 付近に の-置換ペンゼンの吸収が新たに生した ことが観察された。また，硫酸中ではモデル化合物〔4〕の揚合 と同様赤く発色し， $431 \mathrm{~nm}$ 付近に㖟収插大が現われた。一例と して, $m$-フェニレンジミンからのポリフミドの可視吸収スペ

Table 2 Results of polymer reaction

\begin{tabular}{|c|c|c|c|c|c|c|c|}
\hline Ar & $\begin{array}{c}\text { Reaction } \\
\text { time(hr) }\end{array}$ & $\begin{array}{l}\text { Yield } \\
(\%)\end{array}$ & $\begin{array}{c}\text { Conversion } \\
(\%)\end{array}$ & $\begin{array}{l}\eta_{\mathrm{inh}}{ }^{a)} \\
(\mathrm{d} l / \mathrm{g})\end{array}$ & $\begin{array}{l}\eta_{\ln \mathrm{h}^{a)}} \\
(\mathrm{d} l / g)\end{array}$ & $\begin{array}{l}\mathrm{H}_{2} \mathrm{SO}_{4} \\
\lambda_{\text {max }} \\
(\mathrm{nm})\end{array}$ & Color \\
\hline & 2 & 54 & 97 & 0.26 & $0.17^{b)}$ & 432 & Light $\tan$ \\
\hline & 3 & 91 & 99 & 0.29 & $\left.0.17^{b}\right)$ & 433 & $\begin{array}{l}\text { Light } \\
\text { brown }\end{array}$ \\
\hline & 3 & 64 & 93 & 0.29 & $0.20^{b)}$ & 428 & Light $\tan$ \\
\hline & 4 & 80 & 78 & 0.36 & - & 430 & Yellow \\
\hline
\end{tabular}

a) $0.5 \mathrm{~g} / 100 \mathrm{ml}$ conc. $\mathrm{H}_{2} \mathrm{SO}_{4}$ at $30^{\circ} \mathrm{C}$.

b) After treating at $150^{\circ} \mathrm{C}$ in vacuum for $2.5 \mathrm{hr}$. 


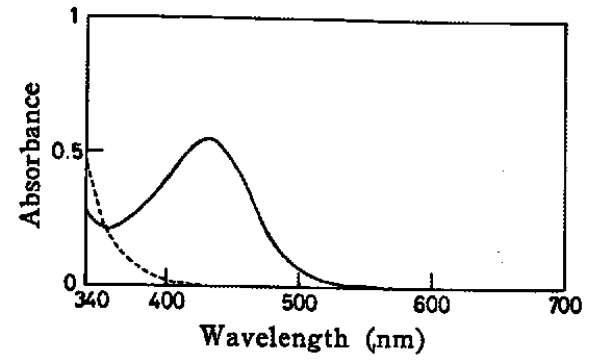

Fig. 2 Visible spectra of polyamides in conc. $\mathrm{H}_{2} \mathrm{SO}_{4}$

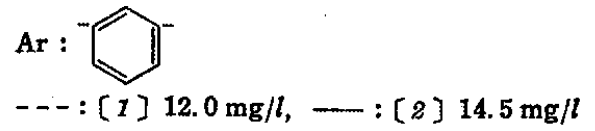

トクルを図 2 K示す。この $\lambda_{\max }$ Kおけるモル吸光係数がポリマ 一に括いてすデル化合物 [4] と同し值をとるすのと仮定して, 一定試料中K乱けるキノキサリン単位の数を求め、それをキノキ サリン生成の反応率とした。ベンジジンからのポリアミドの洯合 を除いた均一系では，93\% 以上の高い反席率を示している。

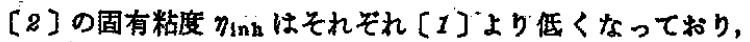
また[2]を[1]と同様に鶖处理すると $\eta_{\operatorname{lnh}}$ がいらじるしく低 下した。この原因は明らかでない。

ベンジジンからのボリアミドの場合は，以上述べたことと多少 異なる条件て反応を行なった。ベンジシンからのポりてミド[1] は熱观理によって一部不溶部が生じたるのをそのまま用いたため， 反応恃不均一で行なわれた。生成物は $\mathrm{NMP}$ (含 $\mathrm{LiCl}$ ) 可溶部 (收 率 $18 \%$ ) と不溶部 (62\%) にわけられ，不溶部にはキノキサリン 環は生成していなかった。したがって，収率は雨者の合計である が，反㐫率は可溶部のみを対象とした。可溶部の固有粘度は 0.36 と比較的高い值を示しているので, 熱処理は行なわなかった。

3.4 ホリアミト[1]と[2]の溶解性の比皎

[1]と[2]の各種溶媒における溶解性を比較し，表 3 にまと

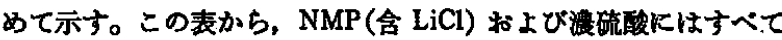

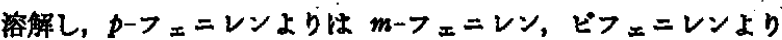
はオキシジフェニレンの方が浴けやすいことがかかる。またキ। キサリン摆の萁入により，溶解性が向上することが認められた。

\section{5 ポリアミド[1]と[2]の熱的性畟の比較}

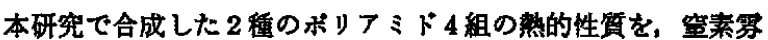
囲気下，DTA，DSC，TG により淍定し，検討を加えた。

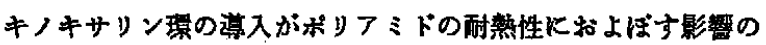

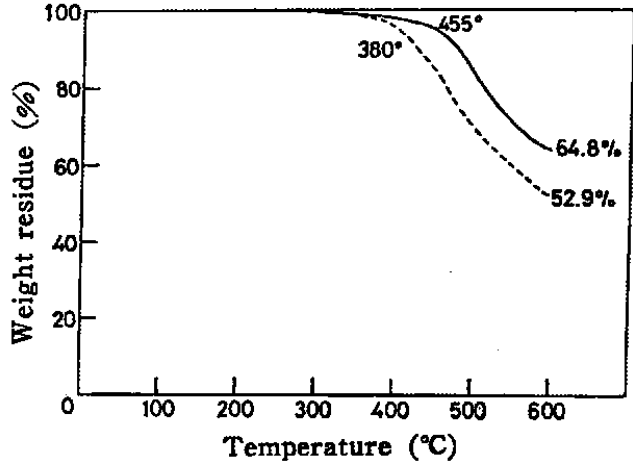

Fig. 3 TGA curves of two types of polyamides (in $\mathrm{N}_{2}, \Delta T=10^{\circ} \mathrm{C} / \mathrm{min}$ )

$$
---:[1], \ldots:[2]
$$

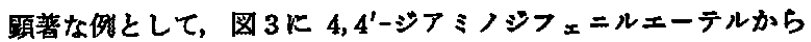
合成したボリアミド[1]と[2]の TGA 曲線を示す。図 $3 に$ 示すよらに, キノキサリシ環を含まないポリてミドは, $380^{\circ} \mathrm{C} か$ ら分解が始まるが，キノキサリン謤を含むポリフミドでは $455^{\circ} \mathrm{C}$ まで分解が起こらず安定である。また $600^{\circ} \mathrm{C}$ における牫存率る [2]は[1]よりる高い。

つぎに，キノキサリン環を有するが，ジアミン単位の構造の異 なるポリフミドでは酎熟珄がどの上うに異なるかを調へた TGA 曲線が図 4 である。分解開始温度 $\left(T_{\mathrm{d}}\right)$ お゙び $600^{\circ} \mathrm{C}$ Kまける 残存率から，主鎖にベンゼン環を多く含むるのの方が䙳熱性にす ぐれていることがわかる。

上K述べたことを含め，DTA，DSC，TG によって得られた結 果を表 4 Kまとめて示す。融点 $T_{\mathrm{m}}$ はDTA とDSC における 吸熱ピークとして判断した。ほとんどが不明確で，表 4 において b, $m$-フェニンジフミンからの[2]はとるかく, 4, 4'-ジフ ミノジフェニルェーテルからの[2]は一層不明確で, 他のポり アミドと闹様， $T_{\mathrm{m}}$ は明確に現われなかった。したがって，注と えどのボリアミドは[1]る〔2〕す無定形であると考えられる。

$T_{d}$ はポリマーの分解開始温度として，TGA 曲線における重 量減少の始まる温度を，接線を引いて求めた。 ミンからのポリアミドの場合[1]の $T_{\mathrm{d}}$ 㤌[2]のそれよりる高 いが, TGA 曲線は注とんど変わらない。したがってほぼ同一の 耐熱性をるつとみなされる。ベンジジンからのポリアミドの啰合 は[1]と[2]は同じ $T_{\mathrm{d}}$ をち，かつるっとるすぐれた酎熱性

Table 3 Solubility of polyamides containing $\alpha$-diketone [1] and quinoxaline ring [2]

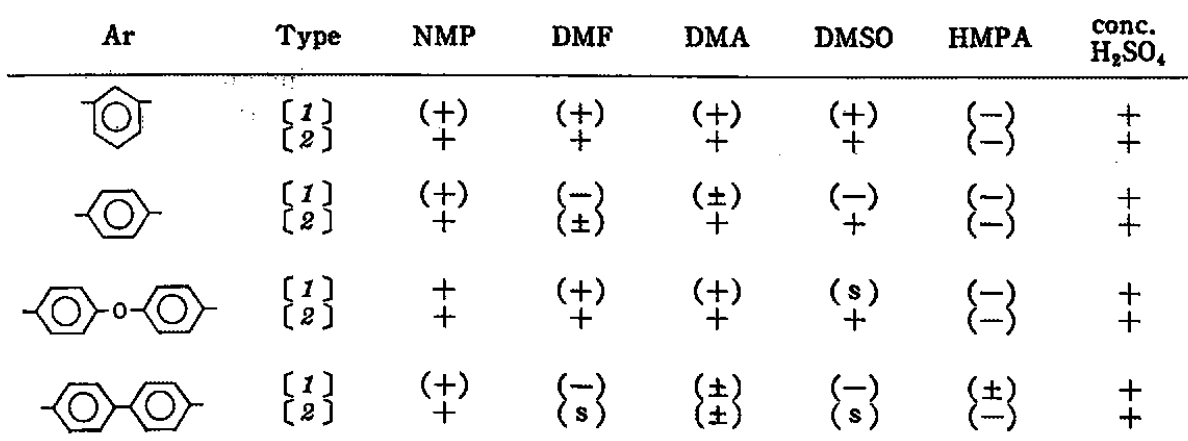

+ : Soluble, \pm : Partially soluble, - : Insoluble, s : Swelling, ( ): With LiCl. 


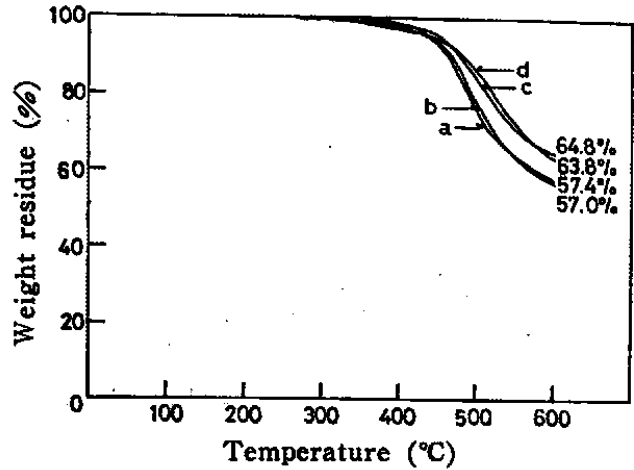

Fig.4 TGA curves of polyamides containing quinoxaline ring (in $\mathrm{N}_{2}, \Delta T=10^{\circ} \mathrm{C} / \mathrm{min}$ ) $\operatorname{Ar}\left(T_{\mathrm{d}}\right)$

a :<smiles>[c]1ccccc1</smiles>

$\left(450^{\circ} \mathrm{C}\right) ;$

(O) $\left(450^{\circ} \mathrm{C}\right)$

c:

$\left(455^{\circ} \mathrm{C}\right.$

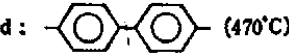

を示した。 $m$ ーフェニレンジフミンおよび 4, 4'-ジアミノジフェニ ルエーテルからのポリフミドの揚合は $[2]$ は[1]よりる高い $T_{\mathrm{d}}$ を示し，耐熱性が向上していることが諰められた。

以上のことからつぎのように結論することができる。かーフェ二 レンジフミン括よびベンジジンからのボリフミドの場合，[1]は ณージケトン結合が熱的に安定てあるのと同時に, ジフミンる対称 性がよく㓮直な構造を有するために，すとると酎熱性がすくれて いた。とくにベンジジンの场合，その共鳴安定化はいちじるしい。

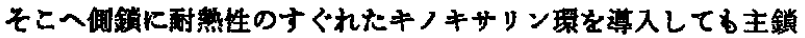
の構造からくる耐熱性に影整を与えることはなかった。しふしな がら, '非対称の $m$ ーフェニレンジフミンおよび屈曲性のある 4, 4'-
Table 4 Thermal properties of polyamides containing $\alpha$-diketone [1] and quinoxaline ring [2]

\begin{tabular}{|c|c|c|c|}
\hline Ar & Type & $\left.T_{\mathrm{m}}\left({ }^{\circ} \mathrm{C}\right)^{a}\right)$ & $\left.T_{\mathrm{d}}\left({ }^{\circ} \mathrm{C}\right)^{b}\right)$ \\
\hline & {$\left[\begin{array}{l}1 \\
2\end{array}\right]$} & $\overline{385}$ & $\begin{array}{l}390 \\
450\end{array}$ \\
\hline & $\left\{\begin{array}{l}1 \\
2\end{array}\right\}$ & $\overline{-}$ & $\begin{array}{l}465 \\
450\end{array}$ \\
\hline & $\left\{\begin{array}{l}1 \\
2\end{array}\right\}$ & $\overline{375}$ & $\begin{array}{l}380 \\
455\end{array}$ \\
\hline & $\left\{\begin{array}{l}1 \\
2\end{array}\right\}$ & - & $\begin{array}{l}470 \\
470\end{array}$ \\
\hline
\end{tabular}

a) Measured by means of DTA and DSC (in $\mathrm{N}_{2}$, $\Delta T: 10^{\circ} \mathrm{C} / \mathrm{min}$ ).

b) Polymer decomposition temperature measured by means of $\mathrm{TG}$ (in $\mathrm{N}_{2}, \Delta T: 10^{\circ} \mathrm{C} / \mathrm{min}$ ).

ジフミノジフェニルェーテルからのポリフミドについては, [1] は $400^{\circ} \mathrm{C}$ を越える酎熱性は得られなかったが，僋鎖にキノキサり ン環を導入することによりいちじるしく耐熱性が同上した。キノ キサリン環の導入といらことは，分子の桹造の面から見ると， $\alpha$ ジケトンの直交する平面を同一平面にるってくることにより，共 鳴安定化と鎖の刷值化に買献する。同時に，そのかさ高い基がポ リマー鎖にぶらさがることにより，温度変化にともなうセグメン トの動きを妨げるのではないかと考えられる。

本研究を遂行するにあたり，実䀫の一部に協力していただいた

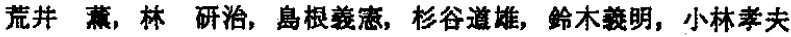
の諸氏に感謝するととすに，元莱分析を行なっていただいた東京 工業大学資源化学研究所の紊藤豊治氏飞深い惑懒の意を表しま す。

（1975 年 5 月，第 24 回高分子学会年次大会(一部) 発表)

\title{
Preparation of Polyamides Containing $\alpha$-Diketone Linkage and Their Quinoxaline Derivatives
}

\author{
Kuniharu Nagakubo, Fumihiko Akutsu, Nobuo Kawamura \\ and Masatoshi Miura \\ Department of Synthetic Chemistry, Faculty of Engineering, \\ Chiba University; Yayoi-cho, Chiba-shi 280 Japan
}

Polyamides containing $\alpha$-diketone linkage in their main chains were prepared in terms of the method of low-temperature solution polycondensation of $4,4^{\prime}$-bis (chloroformyl) benzil with aromatic diamines in $N$-methylpyrrolidone (NMP) - $\mathrm{LiCl}$ solution. The resulting polyamides were allowed to react with $o$-phenylenediamine to give polyamides containing quinoxaline ring in their side chains. Thermal properties of these polyamides were characterized by means of DTA, DSC, and TGA. It was found that polyamides of $m$-phenylenediamine and $4,4^{\prime}$-diaminodiphenyl ether containing quinoxaline ring were thermally more stable than the corresponding parent polyamides containing $\alpha$-diketone linkage. 